\title{
Short Communication: Cyrtodactylus elok Dring, 1979 (Sauria, Gekkonidae): A first country record for Thailand
}

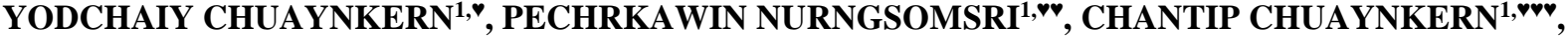

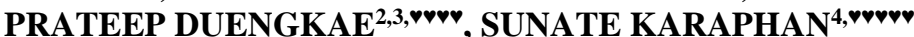 \\ ${ }^{1}$ Department of Biology, Faculty of Science, Khon Kaen University, Mueang Khon Kaen, Khon Kaen, 40002, Thailand \\ Tel.: +668-6005-2507, `email: yodchaiy@kku.ac.th; ${ }^{\text {}}$ email: Pechrkawin@nsm.or.th; ${ }^{\text {vv} e m a i l: ~ i c h a n t @ k k u . a c . t h ~}$

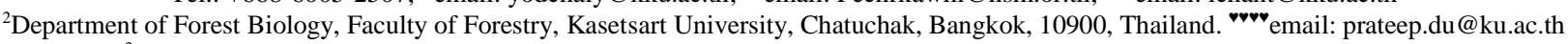 \\ ${ }^{3}$ Center for Advanced Studies in Tropical Natural Resources, Kasetsart University. Chatuchak, Bangkok, 10900, Thailand. \\ ${ }^{4} \mathrm{~Pa}$ Phru-Pa Bala Wildlife Research Station, Waeng, Narathiwat, 96160, Thailand. ${ }^{\text {} v v v e m a i l: ~ k a r a p a n n @ g m a i l . c o m ~}$
}

Manuscript received: 17 August 2018. Revision accepted: 26 October 2018.

\begin{abstract}
Chuaynkern Y, Nurngsomsri P, Chuaynkern C, Duengkae P, Karaphan S. 2018. Short Communication: Cyrtodactylus elok Dring, 1979 (Sauria, Gekkonidae): A first country record for Thailand. Biodiversitas 19: 2111-2117. The present work reports a new country record for Thailand of the bent-toed gecko Cyrtodactylus elok Dring, 1979 based on a single specimen which was collected from Hala-Bala Wildlife Sanctuary, Narathiwat Province (southern Thailand). The Thai specimen shows morphological characters similar to C. elok as follows: 12-14 supralabials, 10-11 infralabials, seven tubercles across midbody, 49 ventral scales, enlarged femoral scales absent, tubercles on forelimbs absent, ventrolateral fold poorly defined, and large tubercles of dorsolateral caudal rows. The species was previously known from the discovery made in Malaysia. This addition brings the number of Thai prehensile-tailed species to three. Morphological and distributional maps are provided.
\end{abstract}

Keywords: Cyrtodactylus brevipalmatus, Cyrtodactylus elok, Narathiwat, new record, prehensile-tailed

\section{INTRODUCTION}

Presently, the bent-toed geckos genus Cyrtodactylus Gray, 1827 have paid attention to their diversity and approximately 260 species were recognized across Asia and western Pacific (Uetz et al. 2018). The prehensiletailed Cyrtodactylus is a group of species with spiny, prehensile tails (Grismer et al. 2010), and presently comprise of nine nominal species: $C$. interdigitalis Ulber, 1993, C. elok Dring, 1979, C. brevipalmatus (Smith, 1923), C. spinosus Linkem, McGuire, Hayden, Setiadi, Bickford and Brown, 2008, C. stresemanni Rösler and Glaw, 2008, C. nuaulu Olivier, Edgar, Mumpuni, Iskandar and Lilley, 2009, C. serratus Kraus, 2007, C. lateralis (Werner, 1896), and $C$. durio Grismer, Anuar, Quah, Muin, Chan, Grismer and Ahmad, 2010. Among these members, two of them were known to occur in Thailand: $C$. brevipalmatus, and $C$. interdigitalis. The first species was described based on specimens collected from Khao Luang National Park, Nakhon Si Thammarat Province (Smith 1923). To date, $C$. brevipalmatus is currently endemic to Thailand (Grismer 2008; Harvey et al. 2016) and its distribution was reported in Tak, Nakhon Si Thammarat, Phetchaburi, Uthai Thani Provinces (Nabhitabhata et al. 2004; Nabhitabhata and Chan-ard 2005; Chuaynkern and Chuaynkern 2012).

The second species, $C$. interdigitalis, was described based on specimens collected from Nam Nao National Park, Phetchabun Province (Ulber 1993). Although several works (see e.g., Ulber 1993; Nabhitabhata et al. 2004;
Nabhitabhata and Chan-ard 2005; Chan-ard and Makchai 2011; Chuaynkern and Chuaynkern 2012; Chan-ard et al. 2015) reported distribution of $C$. interdigitalis in many provincial areas (e.g., Tak, Bueng Kan, Phetchaburi, Phetchabun, Loei, Nong Khai, Uthai Thani Province), but recently Nurngsomsri et al. (2014) confirmed its distribution only in four provinces including Phetchabun (Nam Nao National Park), Uttaradit (Nam Paad Wildlife Sanctuary), Chaiyaphum (Phu Khiao Wildlife Sanctuary) and Loei (Phu Luang Wildlife Sanctuary).

The present work obtained a female specimen of the prehensile-tailed Cyrtodactylus collected from Hala-Bala Wildlife Sanctuary (Narathiwat Province). The specimen was investigated on its identity by comparing its morphological characteristics to relevant specimens and to morphological characteristics described in the taxonomic literature. As below, this specimen is identified as C. elok and we herein present the details of this investigation.

\section{MATERIALS AND METHODS}

A specimen (KKUC 01145, field number Y 0588) of the prehensile-tailed Cyrtodactylus was deposited in the Khon Kaen University Vertebrates Collection (KKUC, Khon Kaen University, Khon Kaen Province, northeastern Thailand). The specimen was identified by comparing their morphological characters with descriptions in relevant taxonomic works and comparative materials including two 
specimens of $C$. brevipalmatus from the British Museum Natural History (BMNH, U.K.) and Zoologische Museum Berlin (ZMB, Germany), and three specimens of C. elok from Zoologische Museum Berlin (ZMB, Germany). Measurements were taken with a digital slide-caliper (to the nearest $0.1 \mathrm{~mm}$ ). Measurement is presented in Table 1 . Those of symmetrical characters are given in form of "left/right". Those of the subdigital lamellae formula of fingers and toes are given in form of "basal lamellae: 1: distal lamellae". The "1" indicates that the specimen has small scales interrupt between the basal and distal lamella. Some measurements are similar in definitions with those of previous publications (e.g., Bauer 2002, 2003): SVL, HL, HW, HH, SE, TYE, IN, EN, IUE, AG, LAL, and TAL. The present work conducted under the following animal ethic numbers: U1-04532-2559 (CC), U1-046369-2559 (YC), and U1-05804-2559 (PD).

\section{RESULTS AND DISCUSSION}

Cyrtodactylus elok Dring, 1979 (Figures 1-3).
Cyrtodactylus elok Dring, 1979: 223. Holotype: BMNH 1967.2783. Type locality: "base camp of the Gunung Benom expedition (215 m elevation)", Pahang, Peninsular Malaysia.

\section{Material examined}

Thailand: Narathiwat Province: Hala-Bala Wildlife Sanctuary [KKUC 01145, field number Y 0588]. Comparative materials were $C$. brevipalmatus: Thailand: Nakhon Si Thammarat Province: Khao Luang National Park [BMNH 1946.8.23.11, ZMB 50525], and C. elok: Malaysia [ZMB 64955, 70052-53].

\section{Identification of the specimen}

Identification of the specimen from Thailand was based on comparing with taxonomic works (Taylor 1963; Dring 1979; Grismer 2005, 2008; Grismer et al. 2010). The specimen was allocated to $C$. elok as it was mostly similar to those of publication as follows: tubercle across midbody five to 10 , ventral scales 41-52, enlarged preanal scales six to nine, enlarged femoral scales absent, femoral pore absent, ventrolateral fold pale-edged, two level of ventrolateral

Table 1. Abbreviation and definition of measurements used in this study

\begin{tabular}{|c|c|c|}
\hline Abb. & Characteristics & Definitions \\
\hline SVL & Snout-vent length & Measured from tip of snout to vent \\
\hline $\mathrm{HL}$ & Head length & Measured from tip of snout to back of mandible \\
\hline HW & Head width & Measured at the widest position \\
\hline $\mathrm{HH}$ & Head height & Measured at the highest position \\
\hline RW & Rostral width & Measured the widest distance of rostral \\
\hline RH & Rostral height & $\begin{array}{l}\text { Measured the highest distance between lower and upper edges of rostral in } \\
\text { vertical direction }\end{array}$ \\
\hline ML & Mental length & Measured the longest distance of mental \\
\hline MW & Mental width & Measured at the widest of mental \\
\hline TYD & Ear-opening length & $\begin{array}{l}\text { Measured distance between anterior and posterior through at horizontal } \\
\text { position }\end{array}$ \\
\hline SS & Snout to shoulder length & Measured from tip of snout to shoulder at anterior point of insertion of the arm \\
\hline SE & Snout length & Measured from tip of snout to anterior edge of eye-ball \\
\hline EL & Eye length & $\begin{array}{l}\text { Measured distance between anterior and posterior edges of eye-ball at } \\
\text { horizontal position }\end{array}$ \\
\hline TYE & Tympanum to eye distance & $\begin{array}{l}\text { Measured distance between posterior edge of eye-ball and anterior edge of ear } \\
\text { opening }\end{array}$ \\
\hline SN & Snout to nostril length & Measured from tip of snout to anterior nostril \\
\hline IN & Internarial distance & Measured distance between nostrils \\
\hline EN & Eye to nostril distance & Measured distance between nostril and anterior edge of eye-ball \\
\hline IFE & Distance between anterior corners of eyes & Measured distance between anterior corners of eye-balls \\
\hline IUE & Distance between upper eyelids & Measured distance between upper eyelids at narrowest position \\
\hline IBE & Distance between posterior corners of eyes & Measured distance between posterior corners of eye-balls \\
\hline SPL & Supranasal length & Measured from anterior to posterior edges at the longest position of supranasal \\
\hline SPW & Supranasal width & Measured from the outer and inner edges at the widest position of supranasal \\
\hline $\mathrm{AG}$ & Trunk length & Measured distance between axillary to groin \\
\hline $\mathrm{BH}$ & Body height & Measured at midbody position \\
\hline UAL & Upper arm length & Measured from anterior point insertion of the arm to elbow \\
\hline LAL & Lower arm length & Measured from elbow to base of palmar \\
\hline PAL & Palmar length & Measured from base of palmar to base of $3^{\text {rd }}$ finger \\
\hline FL & Femur length & Measured from center of cloacal to knee \\
\hline $\mathrm{TL}$ & Tibia length & Measured from knee to base of plantar \\
\hline PLL & Plantar length & Measured from base of plantar to base of $3^{\text {rd }}$ toe \\
\hline TAL & Tail length & Measured from center cloacal to tip of tail \\
\hline $\mathrm{F}_{5}-\mathrm{F}_{5}$ & Length of fingers & Measured from base of finger to tip of finger \\
\hline $\mathrm{T}_{1}-\mathrm{T}_{5}$ & Length of toes & Measured from base of toe to tip of toe \\
\hline
\end{tabular}


caudal fringe, tail square-shaped in cross-section, tip of tail rather white. However, the Thai specimen showed some morphological differences from the type specimens: supralabials 12-14 (eight to 11 in the holotype and paratype), infralabials 10/11 (nine to 10 in the holotype and paratype), 49 ventral scale rows at midbody (44 in the holotype), dorsal tubercle rounded weakly conical (dorsal tubercle rather rounded and flattened with a weak median keel holotype), nine enlarged preanal scales (eight to 10 in Grismer 2008).

The specimen from Thailand shows differentiation from C. brevipalmatus (see Tables 2, 3, and Figure 3) by a number of tubercle rows at midbody (six to 10 versus 12 18), in small femoral scale, in a number of subdigital lamellae on $4^{\text {th }}$ toe (11-15 versus 16-19), and in tubercle of dorsolateral caudal row large.

\section{Description of the Thai specimen}

Size and general aspects. Cyrtodactylus of small size (SVL $54.8 \mathrm{~mm}$ ), body slender. Tail complete (TAL 64.8 $\mathrm{mm}$ ), tapering, 1.2 times longer than SVL, square in crosssection.

Head. Head triangular in dorsal view; moderately long (HL/SVL ratio 0.3), 1.3 times longer than wide (HL 15.6 mm, HW $11.6 \mathrm{~mm}$ ); wide (HW/HL ratio 0.7$)$; high $(\mathrm{HH} 8$ $\mathrm{mm}, \mathrm{HH} / \mathrm{HL}$ ratio 0.5), 2 times shorter than head length. Snout triangular-shaped in dorsal view, acuminate-shaped in lateral view, 1.8 times longer (SE $7 \mathrm{~mm}$ ) than eye (EL $3.8 \mathrm{~mm}$ ). Canthus rostralis indistinct, rounded; loreal region weakly inflated. Interorbital space concave, narrower (IUE $2.4 \mathrm{~mm}$ ) than internasal distance (IN 2.6 $\mathrm{mm}$ ); distance between anterior corners of eye-balls (IFE 4 $\mathrm{mm}) 2$ times in distance between posterior corners of eyes (IBE $7.8 \mathrm{~mm}$ ). Nostrils rather rounded, 7 times closer to tip of snout (SN $1.1 \mathrm{~mm})$ than to anterior edge of eye-ball (EN $7.6 \mathrm{~mm}$ ). Eyes small (EL/HL ratio 0.2), 1.8 times shorter than distance between snout to anterior edge of eye-ball. Pupil crenate, vertical. Ear opening oval (TYD $0.5 \mathrm{~mm}$ ), 7.6 times shorter than eye-ball diameter; distance between anterior edge of ear opening and posterior edge of eye-ball (TYE $4.6 \mathrm{~mm}$ ) 9.2 times longer than ear opening diameter.

Table 2. Selected measurements (mm) and morphological characters of Cyrtodactylus elok from Thailand (KKUC 0145) and Malaysia (ZMB64955, 70052-53)

\begin{tabular}{|c|c|c|c|c|}
\hline Characters & $\begin{array}{c}\text { KKUC 01145 } \\
\text { (Subadult) }\end{array}$ & $\begin{array}{c}\text { ZMB } 64955 \\
\text { Female }\end{array}$ & $\begin{array}{c}\text { ZMB 70052 } \\
\text { Female }\end{array}$ & $\begin{array}{c}\text { ZMB 70053 } \\
\text { Female }\end{array}$ \\
\hline$\overline{S V L}$ & 54.8 & 81 & 83 & 77.4 \\
\hline $\mathrm{HL}$ & 15.6 & 21.6 & 23 & 21 \\
\hline HW & 11.6 & 15.6 & 17 & 15 \\
\hline $\mathrm{HH}$ & 8 & 9.5 & 10.6 & 8.9 \\
\hline RL & 1 & 2.1 & 1.7 & 2 \\
\hline RW & 1.6 & 2.7 & 4 & 4 \\
\hline SPL & 0.5 & 0.5 & 0.7 & 0.5 \\
\hline SPW & 1 & 1 & 1.4 & 1.2 \\
\hline ML & 2 & 3 & 2.8 & 3 \\
\hline MW & 1.6 & 2.6 & 2.6 & 2.4 \\
\hline $\mathrm{SN}$ & 1.4 & 2 & 1.8 & 1.9 \\
\hline SE & 7 & 8 & 9.8 & 8.2 \\
\hline SS & 19.8 & 28.5 & 28 & 28.3 \\
\hline IN & 2.6 & 2 & 3 & 14.7 \\
\hline $\mathrm{EN}$ & 4.6 & 6 & 8 & 6.4 \\
\hline IFE & 4 & 5.1 & 7.5 & 6.9 \\
\hline IBE & 7.8 & 10.7 & 14.4 & 12.4 \\
\hline IUE & 2.4 & 3.7 & 3 & 4.4 \\
\hline EL & 3.8 & 6 & 6.5 & 6 \\
\hline TYE & 4.9 & 6.7 & 8.4 & 6.7 \\
\hline TYD & 0.5 & 1 & 0.6 & 1.4 \\
\hline $\mathrm{AG}$ & 24 & 32 & 42 & 35.4 \\
\hline UAL & 9 & 12.4 & 13.7 & 12 \\
\hline LAL & 8 & 10.8 & 13 & 11 \\
\hline FL & 13.9 & 17.4 & 18.7 & 16.3 \\
\hline TL & 10.2 & 14.4 & 15.3 & 13.7 \\
\hline TAL & 64.8 & 84 & - & - \\
\hline Relatively finger length & $\mathrm{F}_{4}>\mathrm{F}_{3}>\mathrm{F}_{5}>\mathrm{F}_{2}>\mathrm{F}_{1}$ & $\mathrm{~F}_{4}, \mathrm{~F}_{3}>\mathrm{F}_{2}>\mathrm{F}_{5}>\mathrm{F}_{1}$ & $\mathrm{~F}_{4}, \mathrm{~F}_{3}>\mathrm{F}_{2}, \mathrm{~F}_{5}>\mathrm{F} 1$ & $\mathrm{~F}_{4}, \mathrm{~F}_{3}>\mathrm{F}_{2}>\mathrm{F}_{5}>\mathrm{F}_{1}$ \\
\hline Relatively toe length & $\mathrm{T}_{4}>\mathrm{T}_{3}>\mathrm{T}_{5}>\mathrm{T}_{2}>\mathrm{T}_{1}$ & $\mathrm{~T}_{4}>\mathrm{T}_{3}>\mathrm{T}_{5}, \mathrm{~T}_{2}>\mathrm{T}_{1}$ & $\mathrm{~T}_{4}>\mathrm{T}_{5}>\mathrm{T}_{3}>\mathrm{T}_{2}>\mathrm{T}_{1}$ & $\mathrm{~T}_{4}>\mathrm{T}_{3}>\mathrm{T}_{4}>\mathrm{T}_{5}>\mathrm{T}_{1}$ \\
\hline Internasal & 1 & 1 & 2 & 1 \\
\hline Tubercle row across middle body & 7 & 7 & 10 & 6 \\
\hline Ventral scale rows & 49 & 41 & 52 & 47 \\
\hline Preanal pores & - & - & 7 minutes pit & - \\
\hline Enlarged preanal scales & 9 & 9 & 8 & 6 \\
\hline Subdigital lamellae under $4^{\text {th }}$ toe & $(9: 1: 6)$ & $(9: 1: 4)$ & $(11: 1: 3)$ & $(10: 1: 4)$ \\
\hline
\end{tabular}




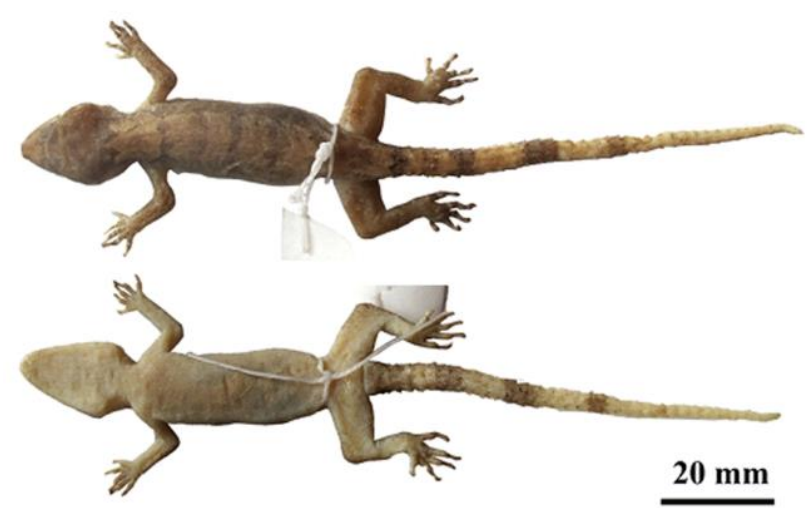

Figure 1. Dorsal and ventral views of Cyrtodactylus elok from Hala-Bala Wildlife Sanctuary in Narathiwat Province (KKUC 01145, SVL $54.8 \mathrm{~mm})$

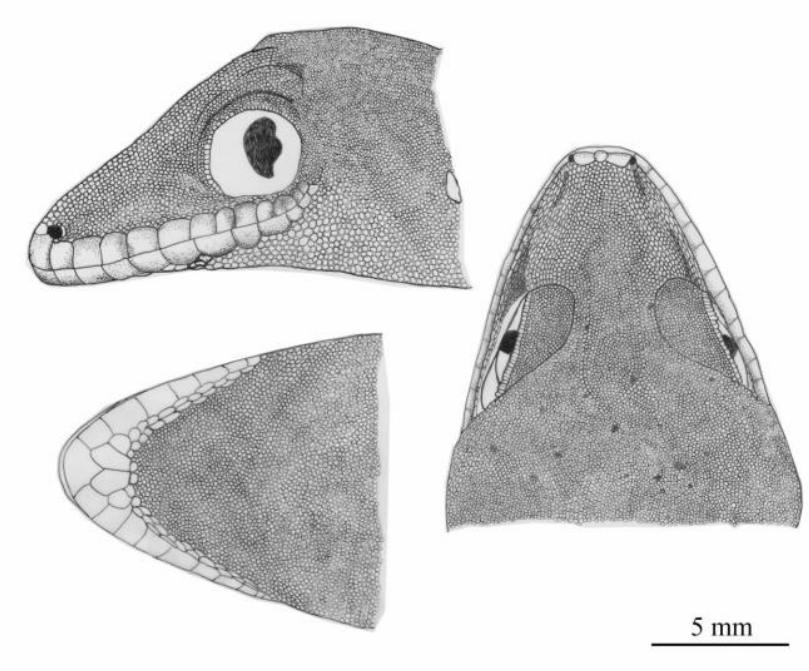

Figure 2. Head illustration of Cyrtodactylus elok (KKUC 01145); lateral (upper left), ventral (lower left) and dorsal (right) views

Body. Body slender, rather rectangular in cross-section; 1.2 times longer (AG $24 \mathrm{~mm}$ ) than snout-shoulder length (SS $19.8 \mathrm{~mm}$ ), 2.3 times shorter than snout-vent length.

Forelimbs. Arm moderately short and slim; upper arm 1.1 times longer (UAL $9 \mathrm{~mm}$ ) than lower arm (LAL 8 $\mathrm{mm}$ ); lower arm 2.7 times longer than hand (PAL $3 \mathrm{~m}) . \mathrm{F}_{4}$ long $(4.6 \mathrm{~mm}) ; F_{3}(4 \mathrm{~mm}), F_{2}(3.7 \mathrm{~mm})$ and $F_{5}(3.4 \mathrm{~mm})$ moderately long; $F_{1}(2.8 \mathrm{~mm})$ short. Relative length of fingers: $F_{4}>F_{3}>F_{2}>F_{5}>F_{1}$. Webbing present.

Hind limbs. Leg moderately short; upper leg 1.4 times longer (FL $13.9 \mathrm{~mm}$ ) than lower leg (TL $10.2 \mathrm{~mm}$ ); lower leg 2.4 times longer than plantar (PLL $4.3 \mathrm{~mm}$ ). $\mathrm{T}_{4}$ long $(6$ $\mathrm{mm}) ; \mathrm{T}_{3}(5.2 \mathrm{~mm}), \mathrm{T}_{5}(5 \mathrm{~mm})$ and $\mathrm{T}_{2}(4.6 \mathrm{~mm})$ moderately long; $\mathrm{T}_{1}(2.7 \mathrm{~mm})$ short. Relative length of toes: $\mathrm{T}_{4}>\mathrm{T}_{3}>$ $\mathrm{T}_{5}>\mathrm{T}_{2}>\mathrm{T}_{1}$. Webbing present.

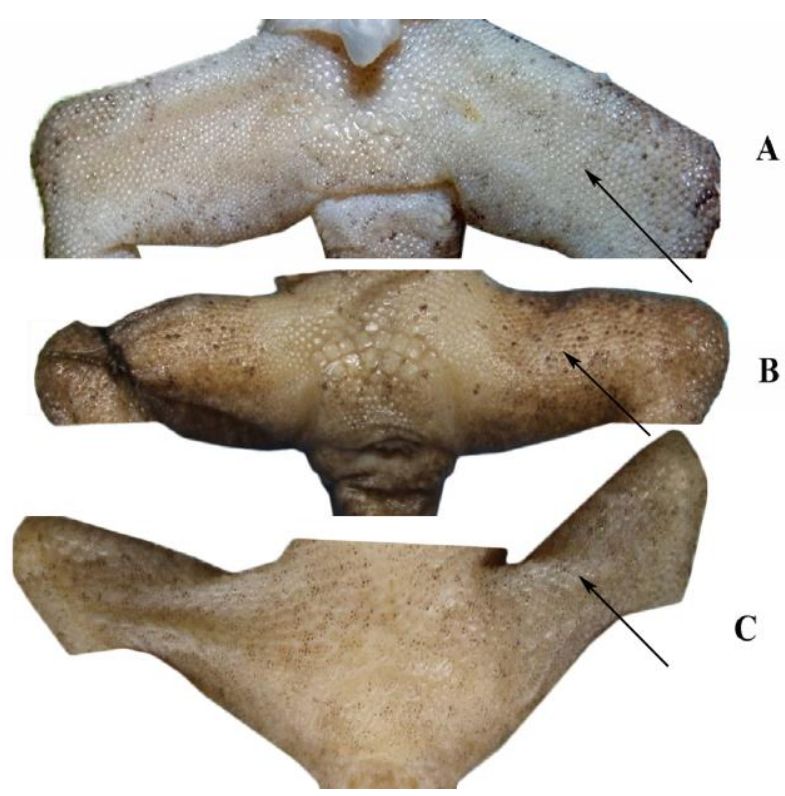

Figure 3. Cloacal and femoral regions comparison between Cyrtodactylus elok (A and B), and C. brevipalmatus (C). A (KKUC 01145, subadult female) and B (ZMB 70052, adult female) shows the absence of enlarged femoral scales. C (ZMB 50525, adult female) shows the presence of enlarged femoral scales. Photographs not scaled. Arrows indicate areas on nonenlarged and enlarged femoral scales

Scalation. Rostral rectangular, 1.6 times wider (RW 1.6 $\mathrm{mm}$ ) than high (RH $1 \mathrm{~mm}$ ), incomplete divided dorsally downward ca $1 / 2$ of rostral height and terminated as $\mathrm{Y}$ shaped; posterior bordered with two supranasals and internasal, lateral bordered with the $1^{\text {st }}$ supralabial and nostril. Supranasal oval, 2 times wider (SPW $1 \mathrm{~mm}$ ) than long (SPL $0.5 \mathrm{~mm}$ ); anterior bordered with rostral, posterior bordered with granular scales on snout region, separated from each other by an internasal. Internasal single, small, anterior bordered with rostral, posterior bordered with granular scales on snout region, lateral bordered with supranasals. Supralabials $12 / 14$, one to 10 equal size and then gradually reduced. Infralabials 10/11; $1^{\text {st }}$ infralabial bordered with mental, $1^{\text {st }}$ and $2^{\text {nd }}$ chinshields, $2^{\text {nd }}$ infralabial bordered with $2^{\text {nd }}$ chinshield and subinfralabials, infralabials three to 11 bordered with subinfralabials. Snout region homogeneous granular scales. Upper eyelids granular scales with few dome weakly conical tubercles. Interorbital region homogeneous granular scales. Occipital region granular scales with few dome weakly conical tubercles. Temporal region granular scales with few dome weakly conical tubercles. Loreal region homogeneous granular scales. Mental triangular, 1.3 times wider (MW $2 \mathrm{~mm}$ ) than long (ML $1.6 \mathrm{~mm}$ ); lateral bordered with $1^{\text {st }}$ infralabial; posterior bordered with $1^{\text {st }}$ chinshield. $1^{\text {st }}$ chinshield trapezoidal; anterior bordered with mental, and $1^{\text {st }}$ infralabial; posterior bordered with small subinfralabials. $2^{\text {nd }}$ chinshield rather rounded, smaller than $1^{\text {st }}$ chinshield; anterior bordered with $1^{\text {st }}$ chinshield, and first-two infralabials; posterior bordered with small subinfralabials. Subinfralabials oval, separated into two 
rows; bordered with $2^{\text {nd }}-6^{\text {th }}$ infralabials and granular gular scales. Gular region homogeneous granular scales. Dorsal granular scales mixed with dome weakly conical tubercles. Dorsal tubercle rows across neck, midbody, and before vent: zero, seven, and three, respectively. Ventral scales rounded, overlapping; 49 ventral scale rows at midbody. Ventrolateral fold poorly defined. Preanal scales enlarged; femoral pores absent. Femoral scales not enlarged, equal size with scales on ventral part of thigh. Preanal pores absent. Dorsal part of upper arm homogeneous granular scales, ventral part rounded homogeneous scales. Dorsal part of lower arm homogeneous granular scales, ventral part rounded homogeneous scales. Palmar: dorsal part granular scales, ventral part rounded scales. Finger distal and basal subdigital lamellae separated by small scales. Finger subdigital lamellae formula: $F_{1}(7: 1: 3), F_{2}(8: 1: 5)$, $F_{3}(9: 1: 5), F_{4}(10: 1: 3), F_{5}(8: 1: 5)$. Dorsal part of upper leg granular scales mixed with dome weakly conical tubercles, ventral part rounded homogeneous scales. Dorsal part of lower leg granular scales mixed with dome, weakly conical tubercles, ventral part rounded homogeneous scales. Plantar: dorsal part granular scales, ventral part rounded scales. Toe distal and basal subdigital lamellae separated by small scales. Toe subdigital lamellae formula: $\mathrm{T}_{1}$ (7:1:5), $\mathrm{T}_{2}$ (9:1:4), $\mathrm{T}_{3}$ (10:1:6), $\mathrm{T}_{4}$ (9:1:6), $\mathrm{T}_{5}$ (6:1:4). Dorsal part of tail granular scales mixed with conical tubercles throughout the tail; ventral part round, small subcaudal scales, no enlarged subcaudal scales. Ventrolateral caudal spiny, alternation of a long spine and 2-3 short spines; prehensile-tailed present.

Coloration (in preservative). Dorsal part of head, body, forelimbs, hind limbs and tail grayish brown (tail tip white); pair of deltoid marking on nuchal, six pale dark brown narrows transverse bands on body; four dark brown caudal bands. Ventral part of head, body, forelimbs, hind limbs and tail grayish brown alternated with the dark brown ring of caudal bands.

Coloration (in life). not available.

\section{Discussion}

Description of a species of $C$. elok in the present work was based on a single subadult female, therefore secondary sex characteristics such as preanal and femoral pores were not available. However, the specimen is clearly belonging to $C$. elok by comparison with taxonomic works of other prehensile-tailed species. Since C. elok has been described as new to science in 1979 by J.C.M. Dring, the species was not recorded outside Malaysia, only new localities and specimens were added to the knowledge on $C$. elok (Grismer 2008; Hervey et al. 2016). The present work added one additional specimen to the species. In an aspect of the distribution of the species, we added Thailand as the second country of its distribution range (Figure 4).

Although the addition of the present work brings the number of Thai prehensile-tailed Cyrtodactylus to three species (i.e., $C$. brevipalmatus, $C$. elok, and $C$. interdigitalis), intensive investigation in terms of taxonomy and distribution of this group is still required. Before 1993, only one species of the prehensile-tailed Cyrtodactylus was known to be found in Thailand: C. brevipalmatus. Smith (1923) described this species based on two specimens from "Khao Luang, Nakhon Si Thammarat Mountains". Subsequent work by Taylor (1963) included $C$. brevipalmatus in the lizard fauna of Thailand but no addition specimens were included in this work. Later, Ulber (1993) described another new species of the prehensile-tailed Cyrtodactylus named $C$. interdigitalis on the basis of five new specimens collected from Phetchabun Province (Nam Nao National Park) by the late Jarujin Nabhitabhata in 1991. This discovery brought the number of this group to two species. Subsequent works such as books and checklists included these two species in the fauna of the country (Nabhitabhata et al. 2004; Nabhitabhata and Chan-ard 2005; Das 2010; Chuaynkern and Chuaynkern 2012; Chan-ard et al. 2015).

Table 3. Comparison of Cyrtodactylus elok and other prehensile-tailed species from Thailand

\begin{tabular}{|c|c|c|c|c|c|c|}
\hline Characters/species & $\begin{array}{c}\text { C. elok } \\
\text { Thailand }\end{array}$ & $\begin{array}{c}\text { C. elok } \\
\text { Malaysia }\end{array}$ & $\begin{array}{l}\text { C. elok } \\
\text { Lit. }\end{array}$ & $\begin{array}{c}\text { C. brevipalmatus } \\
\text { BMNH 1946.8.23.11 }\end{array}$ & $\begin{array}{l}\text { C. brevipalmatus } \\
\text { Lit. }\end{array}$ & $\begin{array}{c}\text { C. interdigitalis } \\
\text { Lit. }\end{array}$ \\
\hline SVL maximum & 54.8 & 83 & 67.5 & 63 & 71 & 80 \\
\hline Infralabials & $10-11$ & $10-12$ & 9 & $10-9$ & $10-10$ & $10-12$ \\
\hline Tubercles across midbody & 7 & $6-10$ & $5-10$ & 16 & 18 & $18-22$ \\
\hline Ventral scales & 49 & $41-52$ & 44 & 40 & 37 & $37-42$ \\
\hline Number of enlarged preanal scales & 9 & $6-9$ & 8 & 9 & $7-10$ & 14 \\
\hline Number of preanal pores & 0 & 0,7 pit & $0\left(0^{7} 8\right)$ & $0^{\prime \prime} 9$ & $0\left(0^{\prime} 9-10\right)$ & $0\left(o^{x} 14\right)$ \\
\hline Enlarged femoral scales & No & No & No & Yes & Yes & yes \\
\hline Number of femoral pores & 0 & 0 & 0 & $6-7$ & $0\left(\sigma^{\top} 6-7\right)$ & $0\left(0^{2} 8-9\right)$ \\
\hline Tubercles on forelimbs & No & No & Yes & Yes & Yes & Yes \\
\hline Ventrolateral fold & Poor & Poor & Poor & Distinct & Distinct & Distinct \\
\hline Tubercle of dorsolateral caudal rows & Large & large & Large & Small & Small & Small \\
\hline Number of subdigital lamellae on $4^{\text {th }}$ toe & 15 & $11-14$ & $18-19$ & 13 & $18-20$ & $18-20$ \\
\hline Two level of ventrolateral c & Yes & Yes & Yes & No & - & No \\
\hline Contact of posterior thigh scales abrupt & No & No & No & Yes & Yes & Yes \\
\hline Tail in cross-section & Square & Square & Square & Slightly circular & Slightly circular & Slightly circular \\
\hline $1 / 3$ tip of tail rather white color & Yes & Yes & Yes & No & - & No \\
\hline Caudal segment & Wide & wide & Wide & Narrow & Narrow & Narrow \\
\hline
\end{tabular}




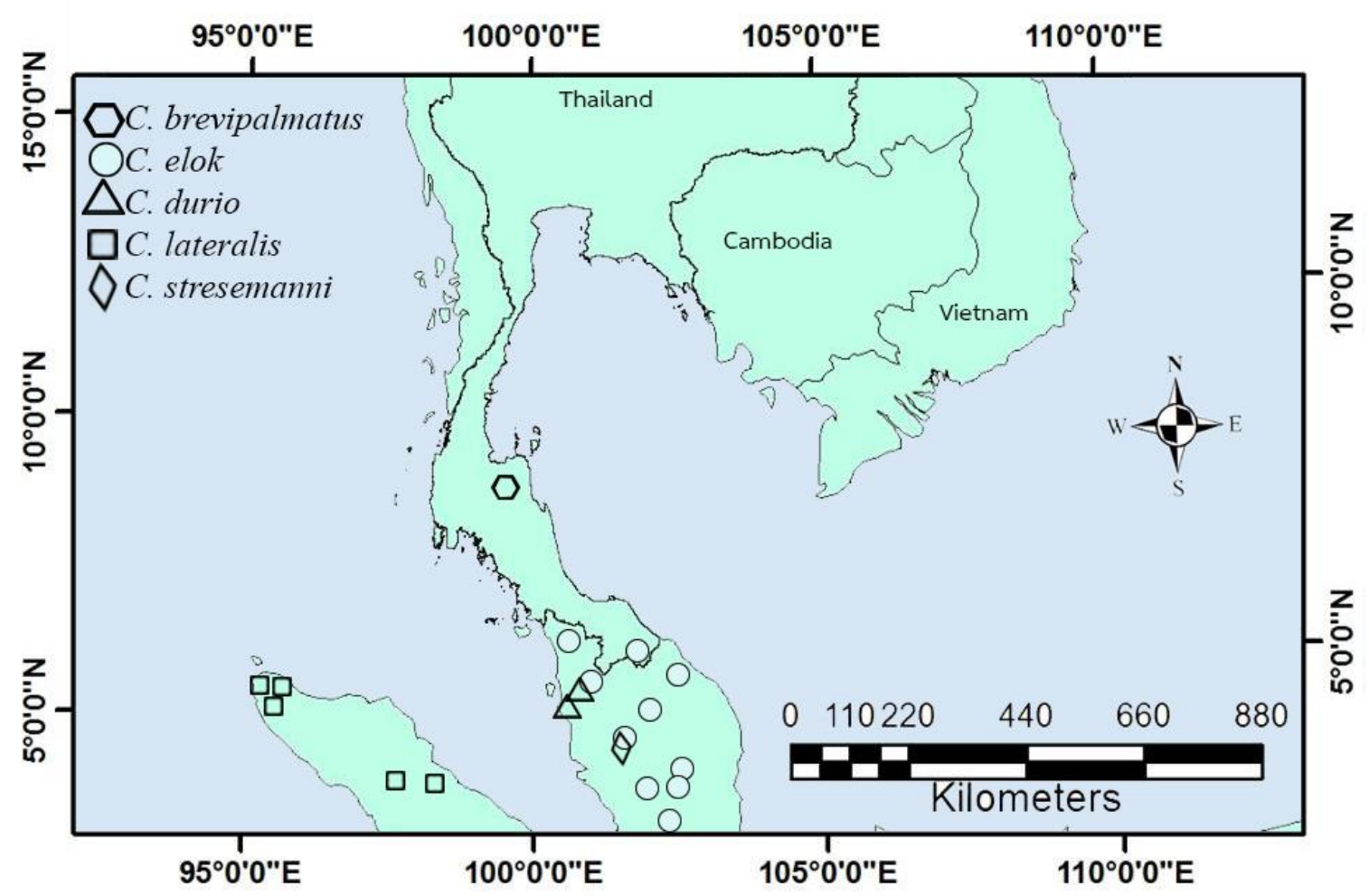

Figure 4. Known distribution of Cyrtodactylus elok (localities of C. brevipalmatus, C. elok [for outside Thailand], C. durio, C. lateralis, and C. stresemanni obtained from Harvey et al. 2016)

The prehensile-tailed Cyrtodactylus comprises of two clades (Harvey et al. 2016), the mainland SE Asian clade (including C. elok, C. interdigitalis, and C. brevipalmatus) and the insular clade (including $C$. durio, C. lateralis, $C$. nuaulu, C. serratus, C. spinosus, and C. stresemanni). Within the mainland SE Asian clade, DNA sequence data based on the NADH Dehydrogenase two-gene (ND2) supports a close relationship between $C$. elok (from Malaysia), and $C$. interdigitalis (from Lao PDR). Unfortunately, DNA sequence data of $C$. brevipalmatus was not available for this analysis. In Harvey et al. (2016), phylogeny based on morphology with three species added to original hypothesis of Grismer et al. (2010) supports a close relationship between $C$. elok and $C$. brevipalmatus with $C$. interdigitalis as a sister species to this clade. Therefore, adding of DNA sequence of $C$. brevipalmatus in further phylogenetic analysis is still required for discovering the phylogenetic position of $C$. brevipalmatus.

Particular the prehensile-tailed Cyrtodactylus recorded from Thailand, the intensive study of taxonomy is still a revision. Since the first species of this group $(C$. brevipalmatus) has been discovered in 1923 (Smith 1923), their extended distribution was added in several works (Cox et al. 1998; Nabhitabhata et al. 2004; Nabhitabhata and Chan-ard 2005; Grismer 2008; Das 2010; Chuaynkern and Chuaynkern 2012; Chan-ard et al. 2015) but such works did not provide information on voucher specimens. Furthermore, the second species ( $C$. interdigitalis) was recorded wider distribution than previously known
(Nurngsomsri et al. 2014). Therefore, additional specimens of this group from overlapping areas (southern part upward through the western to northern Thailand) between $C$. brevipalmatus and $C$. elok, and as well as in the area connected of northern and northeastern Thailand are important for the intensive study in the future.

\section{ACKNOWLEDGEMENTS}

The authors are grateful to following institutes for facilitating this study: Khon Kaen University (Khon Kaen Province, Thailand), Kasetsart University (Bangkok, Thailand), and Department of National Park, Wildlife and Plant Conservation. For loaning and facilitated examining specimens, we also grateful to following institutes and persons: British Museum Natural History (Patrick Campbell), Field Museum of Natural History (Alan Resetar), Khon Kaen University Vertebrates Collection (Dr. Yodchaiy Chuaynkern), Muséum national d'Histoire Naturelle (Prof. Annemarie Ohler), Museum d'Histoire Naturelle, Route de Malagnou (Dr. Andréas Schmitz and Mr Alain Merguin), Museo Civico di Storia Naturale di Genova (Dr. Raffael Ernst), Princess Maha Chakri Sirindhorn Natural History Museum (Dr. Pipat Soisook and Ms Wanitchaya Tirakunpisut), Thailand Natural History Museum (Dr. Somchai Bussarawit, Tanya Chan-ard, and Sunchai Makchai), Zoologisches Forschungsmuseum Alexander Koenig and Museum für Tierkunde (Dr. 
Wolfgang Böhme and Mr Morris Flecks), Zoologische Staatssammlung München (Dr. Frank Glaw), Collectiebeheerder Reptielen en Amfibieën (Dr. Esther Dondorp), Zoologische Museum Berlin (Dr. Frank Tillack and Dr. Mark-Oliver Rödel). For grants, this work was partially supported by the following: (i) the Research Support Scholarship (Ms. Pechrkawin Nurngsomsri), (ii) Funding for graduate students to study abroad (Ms Pechrkawin Nurngsomsri), (iii) Funding for strengthening the research of professors by supporting graduate students (Dr. Yodchaiy Chuaynkern and Ms. Pechrkawin Nurngsomsri). Dr. Prateep Duengkae is the recipient of Research Chair Grant, the National Science and Technology Development Agency (NSTDA), Thailand. Our special thank goes to Dr. Robert H. Orr for assistance with the English-language manuscript.

\section{REFERENCES}

Bauer AM. 2002. Two new species of Cyrtodactylus (Squamata: Gekkonidae) from Myanmar. Proc California Acad Sci 53: 75-88.

Bauer AM. 2003 Descriptions of seven new Cyrtodactylus (Squamata: Gekkonidae) with a key to the species of Myanmar (Burma). Proc California Acad Sci 54: 463-498.

Chan-ard T, Makchai S. 2011. Catalogue of type specimens of amphibians and reptiles in the Natural History Museum, National Science Museum, Thailand. Thailand Nat Hist Mus J 5: 113-123.

Chan-ard T, Parr JWK, Nabhitabhata J. 2015. A Field Guide to the Reptiles of Thailand. Oxford University Press, New York.

Chuaynkern Y, Chuaynkern C. 2012. A checklist of reptiles in Thailand. J Wildl Thailand 19: 75-162.

Cox MJ, van Dijk PP, Nabhitabhata J, Thirakupt K. 1998. A Photographic Guide to Snakes and Other Reptiles of Thailand, Singapore \& Peninsular Malaysia. Ralph Curtis Publishing, Sanibel Island.
Das I. 2010. A Field Guide to the Reptiles of South-East Asia. New Holland Publishers, London.

Dring JCM. 1979. Amphibians and reptiles from northern Trengganu, Malaysia, with descriptions of two new geckos: Cnemaspis and Cyrtodactylus. Bull Br Mus Nat Hist Zool 34: 181-241.

Grismer LL. 2005. New species of bent-toed gecko (Cyrtodactylus Gray 1827) from Pulau Aur, Johor, West Malaysia. J Herpetol 39: 424-432.

Grismer LL. 2008. On the distribution and identification of Cyrtodactylus brevipalmatus Smith, 1923, and Cyrtodactylus elok Dring, 1979. Raffles Bull Zool 56: 177-179.

Grismer LL, Anuar S, Quah E, Muin MA, Chan KO, Grismer JL, Ahmad N. 2010. A new spiny, prehensile-tailed species of Cyrtodactylus (Squamata: Gekkonidae) from Peninsular Malaysia with a preliminary hypothesis of relationships based on morphology. Zootaxa 2625: 40-52.

Harvey MB, O'Connell KA, Wostl E, Riyanto A, Kurniawan N, Smith EN, Grismer LL. 2016. Redescription Cyrtodactylus lateralis (Werner) (Squamata: Gekkonidae) and phylogeny of the prehensiletailed Cyrtodactylus. Zootaxa 4107: 517-540.

Nabhitabhata J, Chan-ard T. 2005. Thailand Red Data: Mammals, Reptiles and Amphibians. Office of Natural Resources and Environmental Policy and Planning, Bangkok.

Nabhitabhata J, Chan-ard T, Chuaynkern Y. 2004. Checklist of Amphibians and Reptiles in Thailand. Office of Environmental Policy and Planning, Bangkok.

Nurngsomsri P, Chuaynkern Y, Chuaynkern C, Duengkae P, Sribandit P, Wongnak T, Ittiporn K, Ouchan C, Eimampai K. 2014. Variation and recent distribution of Cyrtodactylus interdigitalis Ulber, 1993 from Thailand. In: Proceedings of the $40^{\text {th }}$ Congress on Science and Technology of Thailand (STT40). Khon Kaen University, Khon Kaen, 2 December 2014.

Smith MA. 1923. Notes on reptiles and batrachians from Siam and IndoChina (No. 2). J Nat Hist Soc Siam 6: 47-53.

Taylor EH. 1963. The lizards of Thailand. Univ Kansas Sci Bull 44: 6871077.

Uetz P, Freed P, Hošek J. 2018. The reptile database. http://www.reptiledatabase.org/, 20 August 2018.

Ulber T. 1993. Bemerkungen über cyrtodactyline Geckos aus Thailand nebst Beschreibungen von zwei neuen Arten (Reptilia: Gekkonidae). Mitt Zool Mus Berlin 69: 187-200. 